\title{
Impact of COVID-19 on Orthopaedic Surgery: Comparison Between Before and During COVID-19 Pandemic
}

\section{Ravi Bhandari, Mohit Thapa Magar, Sushil Shrestha, Ritesh Sinha, Nirab Kayastha and Bishnu Babu Thapa}

Department of Orthopaedics, Shree Birendra Hospital, Nepalese Army Institute of Health Sciences, Chhauni, Kathmandu, Nepal

\begin{abstract}
Introduction: Orthopaedic surgical activity has been significantly affected by COVID-19 pandemic. The decision to perform operative interventions is based on balancing risk to benefit to the patient and health care workers. Though different guidelines have been published, there is a lack of reliable data on orthopaedic surgical activities. Our study aimed to evaluate the impact of the COVID-19 pandemic on Orthopaedic surgeries comparing with the previous year.

Methods: This was an epidemiological retrospective comparative study conducted at Shree Birendra Hospital, Nepal after taking ethical approval from the Institutional Review Committee of NAIHS. Data of the first four month of orthopaedic surgeries after National lockdown (from March 24 to July 23, 2020) and the same four month period of the previous year (The year 2019) were retrieved. The demographic profiles and operations categories (trauma, elective and infections) were compared between two periods using SPSS 21.

Result: Out of total of 651 patients enrolled, 169 patients operated during the pandemic compared with 482 patients before the pandemic. There was a $65 \%$ reduction in total surgical procedures, $94 \%$ reduction in elective cases and trauma cases were reduced by $29 \%(\mathrm{P}<0.05)$. Implant removal $(107,42.8 \%)$ constituted the highest elective cases in the year 2019.

Conclusions: The orthopaedic surgical procedures were decreased in frequency during COVID-19 because of a decrease in elective cases. The total trauma patients remained more equable during pandemic despite strict lock-down. Health care facilities should consider this during post pandemic recovery.
\end{abstract}

Key words: COVID-19; orthopaedic surgery; pandemic; SARS-COV-2; trauma

Correspondence: Ravi Bhandari, Department of Orthopaedics, Shree Birendra Hospital, Nepalese Army Institute of Health Sciences, Chhauni, Kathmandu, Nepal. Email: contactravi@hotmail.com

DOI: $10.3126 / \mathrm{mjsbh.v20i2.33048}$

Submitted on: $2020-11-24$

Accepted on: 2021-06-14 


\section{INTRODUCTION}

The World Health Organisation on March 11, 2020, has declared the Coronavirus Disease 2019 (COVID-19) outbreak a global pandemic. ${ }^{1}$ Nepal has implemented a Nationwide lockdown from $24^{\text {th }}$ March 2020 to mitigate the spread of disease. Surgeons around the world are facing a challenge in delivering optimum care to patients while protecting both patients and healthcare providers from the pandemic. ${ }^{2}$ Several adjustments have been made in orthopaedic services to deal with the pandemic, balancing risk to benefit ratio.

Most of the papers published on COVID-19 were aimed to propose different guidelines and recommendations on surgical management. ${ }^{3}$ These papers during the initial COVID-19 pandemic were lacking reliable data on surgical activity.

Our study aimed to evaluate the impact of COVID-19 on orthopaedic surgeries at a tertiary level military hospital in Nepal comparing the trends of trauma, elective and infection surgeries before (The year 2019) and during (The year 2020) pandemic.

\section{METHODS}

This was an epidemiological retrospective comparative study done at Shree Birendra Hospital (Tertiary level Military Hospital), Kathmandu, Nepal after taking ethical approval from the Institutional Review Committee of NAIHS. Data were extracted from the records section of the Hospital. Patients who had undergone orthopaedic surgical interventions during the first four months of Nationwide lockdown in Nepal (from March 24 to July 23, 2020) were enrolled in the study. Similarly, data of patients who received operations during the same period in previous the year (The year 2019) before the COVID-19 pandemic were collected.

Patients were divided into two groups: during the pandemic (The year 2020) and before the pandemic (The year 2019) group. The four months of each year was further divided into month $1^{\text {st }}$ (March 24 to April 23), month $2^{\text {nd }}$ (April 24 to May 23), month $3^{\text {rd }}$ (May 24 to June 23), and month $4^{\text {th }}$ (June 24 to July 23) of the year 2020 and year 2019 chronologically. The demographic profiles of the patient were recorded. The operations categories were divided into three types as trauma, elective and infections. The elective surgery includes those that can be delayed without significant difference in eventual outcome or harm to the patient. ${ }^{4}$ The trauma category was further sub-divided according to anatomic distributions as the upper limb, lower limb, spine, pelvis and acetabulum and soft tissue. The elective category was sub-divided into implant removal, sports and arthroscopy, joint replacement, spine and others. The infection category includes osteomyelitis, septic arthritis and soft tissue infections. This can be after an open fracture or after a surgical procedure like surgical site infection, implant associated infections etc.

During the pandemic, initially a screening questionnaire with relevant signs and symptoms and exposure or recent travel history dictated the need for nasopharyngeal swab RT-PCR testing for operating patients. Later institutional policy changed that indicated nasopharyngeal swab RTPCR testing for all orthopaedic surgeries. A protocol for universal testing for all orthopaedic surgery admissions is valid as the study from orthopaedic speciality hospital from New York revealed a high percentage of asymptomatic infections with COVID-19 in patients admitted for orthopaedic surgery. ${ }^{5}$ No patients reported SARSCOV-2 positive.

We used Statistical Package for Social Sciences (SPSS) software program version 21 for data analysis. Categorical variables were analysed using chi-square test and results were presented as frequencies and percentages. Continuous variables results were presented as mean \pm standard deviation (SD). A difference in a P-value $<0.05$ was considered statistically significant.

\section{RESULT}

A total of 651 patients were analysed. Total 169 patients operated during the pandemic period (The year 2020) were compared with 482 patients in the same months of the previous year in 2019 (Figure 1). This represents a reduction of total orthopaedic operations by $65 \%$ during the pandemic period.

There were $463(71.1 \%)$ male patients and 188 $(28.9 \%)$ female patients with an average age of $37.88 \pm 19.368$ (range 2 to 88 years). In the pandemic period out of 169 patients, $125(74 \%)$ were males and $44(26 \%)$ were females. The mean 
Pandemic period (Year 2020)

Before Pandemic (Year 2019)

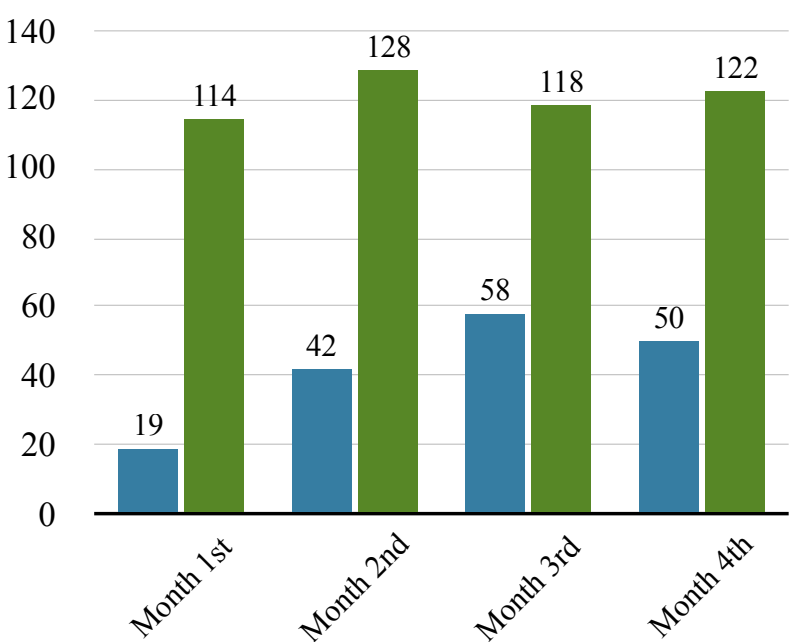

Figure 1. Bar diagram showing monthly comparison of total operated cases during pandemic and before pandemic at same months of period

age was $34.21 \pm 19.307$ years (range 2 to 87 years). In the year 2019 there were total of 482 patients, $338(70.1 \%)$ male and $144(29.9 \%)$ female. The mean age of patients was $39.17 \pm 19.244$ ranging from two to 88 years. Out of total patients in each group, children below 14 years were $30(17.8 \%)$ during the pandemic period and $51(10.6 \%)$ in year 2019. Elderly patients above 65 years were 12 (7.1\%) during pandemic and $56(11.6 \%)$ in year 2019 .

Of total 651 patients there were $356(54.7 \%)$ trauma cases, $265(40.7 \%)$ elective cases and 30 $(4.6 \%)$ infections (Table 1). The ratio of trauma to elective operations was increased from 0.832:1 to 9.86:1 during the pandemic. Elective operations were decreased by $94 \%$ during the pandemic. There was a significant difference in the trauma, elective and infection cases during the pandemic and
Table 1. Differences in total orthopaedic operations categories during and before pandemic

\begin{tabular}{|c|c|c|c|c|c|}
\hline Groups & $\begin{array}{c}\text { Trauma } \\
\text { n (\%) }\end{array}$ & $\begin{array}{c}\text { Elective } \\
\text { n }(\%)\end{array}$ & $\begin{array}{l}\text { Infecti } \\
\text { ons } \\
\text { n }(\%)\end{array}$ & $\begin{array}{l}\text { Total } \\
\text { n (\%) }\end{array}$ & $\begin{array}{c}\text { P- } \\
\text { value }\end{array}$ \\
\hline $\begin{array}{l}\text { Pandemic } \\
\text { period } \\
\text { (year } \\
2020 \text { ) }\end{array}$ & $\begin{array}{r}148 \\
(87.6 \%)\end{array}$ & $\begin{array}{r}15 \\
(8.9 \%)\end{array}$ & $\begin{array}{r}6 \\
(3.6 \%)\end{array}$ & $\begin{array}{r}169 \\
(100 \%)\end{array}$ & 0.000 \\
\hline $\begin{array}{l}\text { Before } \\
\text { pandemic } \\
\text { (year } \\
2019 \text { ) }\end{array}$ & $\begin{array}{r}208 \\
(43.2 \%)\end{array}$ & $\begin{array}{r}250 \\
(51.9 \%)\end{array}$ & $\begin{array}{r}24 \\
(5.0 \%)\end{array}$ & $\begin{array}{r}482 \\
(100 \%)\end{array}$ & \\
\hline
\end{tabular}

previous year $\left(\mathrm{X}^{2}=102.517, \mathrm{P}<0.05\right)$. Infections cases were decreased from $(24,5.0 \%)$ to $(6,3.6 \%)$ during the pandemic period.

Among total of 356 trauma patients, 148 upper limb fractures were accounting $41.6 \%$, followed by lower limb $(137,38.5 \%)$, soft tissue injury (53, $14.9 \%)$, spine $(14,3.9 \%)$, pelvis and acetabulum $(4,1.1 \%)$ (Table 2). The anatomical distribution of trauma cases during the year 2020 and the year 2019 was statistically significant $\left(\mathrm{X}^{2}=12.411, \mathrm{P}<\right.$ $0.05)$. During the pandemic lower limb trauma was $45.3 \%$. This was followed by upper limb (35.1\%) and together they accounted for $80.4 \%$ of all trauma cases. Before pandemic upper limb trauma (46.2\%) was followed by lower limb (33.7\%) with a total of $79.9 \%$. Both upper and lower limb trauma was commonest, accounting for almost $80 \%$ of trauma in either period followed by soft tissue trauma operations.

During the study period 265 elective surgeries were performed (Table 3). There was the statistical significance of elective cases between two years $\left(\mathrm{X}^{2}=15.461, \mathrm{P}<0.05\right)$. The most common elective procedure was implant removal $(107,42.8 \%)$ followed by sports and arthroscopy $(58,23.3 \%)$

Table 2. Differences in orthopaedic trauma operations according to anatomical distribution during and before pandemic

\begin{tabular}{|c|c|c|c|c|c|c|c|}
\hline Groups & $\begin{array}{l}\text { Upper limb } \\
\text { n (\%) }\end{array}$ & $\begin{array}{l}\text { Lower limb } \\
\text { n (\%) }\end{array}$ & $\begin{array}{l}\text { Spine } \\
\text { n }(\%)\end{array}$ & $\begin{array}{l}\text { Pelvis and } \\
\text { acetabulum } \\
\text { n (\%) }\end{array}$ & $\begin{array}{c}\text { Soft tissue } \\
n(\%)\end{array}$ & $\begin{array}{l}\text { Total } \\
\text { n }(\%)\end{array}$ & P-value \\
\hline $\begin{array}{l}\text { Pandemic period } \\
\text { (year 2020) }\end{array}$ & $\begin{array}{r}52 \\
(35.1 \%)\end{array}$ & $\begin{array}{r}67 \\
(45.3 \%)\end{array}$ & $\begin{array}{r}10 \\
(6.8 \%)\end{array}$ & $\begin{array}{r}1 \\
(7 \%)\end{array}$ & $\begin{array}{r}18 \\
(12.2 \%)\end{array}$ & $\begin{array}{r}148 \\
(100 \%)\end{array}$ & 0.015 \\
\hline $\begin{array}{l}\text { Before pandemic } \\
\text { (year 2019) }\end{array}$ & $\begin{array}{r}96 \\
(46.2 \%)\end{array}$ & $\begin{array}{r}70 \\
(33.7 \%)\end{array}$ & $\begin{array}{r}4 \\
(1.9 \%)\end{array}$ & $\begin{array}{r}3 \\
(1.4 \%)\end{array}$ & $\begin{array}{r}35 \\
(16.8 \%)\end{array}$ & $\begin{array}{r}208 \\
(100 \%)\end{array}$ & \\
\hline
\end{tabular}


Table 3. Differences in orthopaedic elective cases operated during and before pandemic

\begin{tabular}{|c|c|c|c|c|c|c|c|}
\hline Groups & $\begin{array}{l}\text { Implant } \\
\text { removal } \\
\text { n }(\%)\end{array}$ & $\begin{array}{c}\text { Sports \& } \\
\text { arthoroscopy } \\
\text { n }(\%)\end{array}$ & $\begin{array}{c}\text { Joint } \\
\text { replacement } \\
\text { n }(\%)\end{array}$ & $\begin{array}{l}\text { Spine } \\
\text { n }(\%)\end{array}$ & $\begin{array}{l}\text { Others } \\
\text { n }(\%)\end{array}$ & $\begin{array}{l}\text { Total } \\
\text { n }(\%)\end{array}$ & $\begin{array}{c}\mathrm{P}- \\
\text { value }\end{array}$ \\
\hline $\begin{array}{l}\text { Pandemic period } \\
\text { (year 2020) }\end{array}$ & $\begin{array}{r}4 \\
(26.7 \%)\end{array}$ & $\begin{array}{r}0 \\
(0 \%)\end{array}$ & $\begin{array}{r}0 \\
(0 \%)\end{array}$ & $\begin{array}{r}4 \\
(26.4 \%)\end{array}$ & $\begin{array}{r}7 \\
(46.7 \%)\end{array}$ & $\begin{array}{r}15 \\
(100 \%)\end{array}$ & 0.002 \\
\hline $\begin{array}{l}\text { Before pandemic } \\
\text { (year 2019) }\end{array}$ & $\begin{array}{r}107 \\
(42.8 \%)\end{array}$ & $\begin{array}{r}58 \\
(23.2 \%)\end{array}$ & $\begin{array}{r}13 \\
(5.2 \%)\end{array}$ & $\begin{array}{r}18 \\
(7.2 \%)\end{array}$ & $\begin{array}{r}54 \\
(21.6 \%)\end{array}$ & $\begin{array}{r}250 \\
(100 \%)\end{array}$ & \\
\hline
\end{tabular}

before the pandemic in the year 2019. Only 15 elective cases were performed during the pandemic. Four implant removals out of which two were planning to go for united mission service, one implant associated infection and one implant failure. Four spine cases, two were cervical myelopathy and two prolapsed inter-vertebral disc disease. Other seven cases were three biopsies, two manipulations under anaesthesia, and two decompressions of neuropathies.

\section{DISCUSSION}

The orthopaedic operations were reduced by $65 \%$ during the pandemic. These decreases in number were because of the lockdown and greatly reduced elective surgeries. This finding of the current study has been supported by many studies. ${ }^{6-8}$

The male is to female ratio of total operations during and before pandemic was constant showing no significant effect of the pandemic in gender distribution. In contrast to the study from Hong Kong, the mean age of patients during the COVID-19 period was low. ${ }^{9}$ Children below 14 years during the pandemic were higher in number than the previous year. It might be because of school closure causing more injuries at home.

There was a monthly progressive rise in the number of operations during the pandemic with a decrease in the last month. Alterations in health care seeking behaviour of patients initially for different reasons like fear of contracting COVID-19 and preferences for private health care facilities could have contributed to changes observed in operations. ${ }^{10}$ Increment in the later month was because of gradual reintroduction of surgical activity and alleviation of strict restrictions of activities by the government.
The total number of operations during the pandemic has fallen significantly. A proportion of this is due to the postponement of elective operations. There was an initial expectation of a greater fall in trauma surgery as a result of lockdown. ${ }^{11,12}$ However, in our study operated trauma cases during pandemic has not been changed significantly. This might be the result of increased household work-related trauma or paradoxically, fewer vehicles causing more road traffic accidents due to over speeding.

Elective operations were reduced by $94 \%$. Reducing elective surgeries saves resources and reduces unnecessary patient flow that eventually decreases the spread of disease among patients and health care workers. ${ }^{13}$ But it showed a huge backlog of elective surgical cases that have great implications and require exceptional attention in post-pandemic recovery. ${ }^{14,15}$ This calls for the development of specific protocols to resume previously cancelled and postponed elective surgeries balancing risk to benefit ratio.

Total infections needing operations was decreased during pandemic might be because of significant reduction of open fractures due to decreased road traffic accidents and reduction in referral volume due to unavailability of transportation facility ${ }^{16}$

In our study, we observed that during pandemic lower limb trauma was higher than upper limb in contrast to the previous year. This might be the result of increasing in low-energy fall in elderly patients causing hip fractures that occur at home, and the incidence may not be impacted by lockdown and decrease road traffic accidents. The elder patients with the trauma of the lower limb and 
limited ambulatory status are more susceptible to respiratory infection; the association between COVID-19 and trauma patients is not unlikely. ${ }^{17,18}$

Another point of interest of our study is that despite the reduction of operations during the pandemic, the operated spinal trauma during the pandemic was high. Operated spine trauma cases were (10, $6.8 \%$ ) similar to a study conducted at Patan Hospital, Nepal (2,5\%). ${ }^{19}$ Fall from height and tree due to increased agricultural activity during pandemic might have contributed to this result. In contrast to our study, a study from Italy showed a $50 \%$ reduction in spine trauma surgery. ${ }^{20}$ Spinal trauma patients are at higher risk for respiratory related infections like influenza. ${ }^{4}$ They are prone to have fever due to other causes like bedsores and urinary tract infections which are the source of viral and bacterial infections.

Reduction of elective surgical procedures like implant removal, arthroscopy and joint replacement during pandemic had contributed to a decrease in the number of hospital admissions. In the time of pandemic, it is important to identify the elective procedures that could be delayed. ${ }^{19,21}$ With no consensus in orthopaedic community the Ohio Hospital Association (OHA) defined elective surgeries as those not meeting the following criteria "threat to the patient's life if surgery or procedure is not performed, the threat of permanent dysfunction of an extremity or an organ system, risk of metastasis or progression of staging, or risk of rapidly worsening to severe symptoms". ${ }^{22}$ Although ours is a novel study involving orthopaedic surgeries during the pandemic, it does have certain limitations. Ours is a single-centre study for a short period time which may not be representative of a national profile, and may not be generalised to the entire nation. Since ours is a military hospital catering to army personnels and their dependents, the injuries and surgeries conducted here may not represent the common National injuries as well as orthopaedic surgeries.

\section{CONCLUSIONS}

The total proportions of operations that have fallen throughout the course of the pandemic are due to a fall in elective cases. The number of trauma operations remained stable. Dealing with the anticipated backlog of elective orthopaedic surgery in post-pandemic scenarios requires planning. Keeping in mind that the trauma cases do not decrease, despite a nationwide lockdown orthopaedic surgeons and health care facilities should consider this during staffing and resource deployment.

\section{ACKNOWLEDGEMENT}

We would like to thank Dr. Bipin Shrestha and Dr. Kanti Prabha Giri for giving valuable inputs during preparation and editing of this manuscript.

To cite this article: Bhandari R, Magar MT, Shrestha,S, Sinha R, Kayastha N, Thapa BB. Impact of COVID-19 on Orthopaedic Surgery: Comparison Between Before and During COVID-19 Pandemic. MJSBH. 2021;20(2):130-5.

Conflict of Interest: None declared

\section{REFERENCES}

1. Cucinotta D, Vanelli M. WHO Declares COVID-19 a Pandemic. Acta Biomed. 2020 Mar;91(1):157-60. DOI: 10.23750/abm.v91i1.9397.

2. Chang Liang Z, Wang W, Murphy D, Po Hui JH. Novel Coronavirus and Orthopaedic Surgery: Early Experiences from Singapore. J Bone and Joint Surg Am. 2020 May;102(9):745-9. DOI: 10.2106/JBJS.20.00236

3. Sarac NJ, Sarac BA, Schoenbrunner AR, Janis JE, Harrison RK, Phieffer LS, et al. A Review of State Guidelines for Elective Orthopaedic Procedures During the COVID-19 Outbreak. J Bone Joint Surg Am. 2020 Jun 3;102(11):9425. DOI: $10.2106 /$ JBJS.20.00510

4. Chhabra HS, Bagaraia V, Keny S, Kalidindi KKV, Mallepally A, Dhillon MS, et al. COVID-19: Current Knowledge and Best Practices for Orthopaedic Surgeons. Indian J Orthop. 2020 May;54(4):1-15. DOI:10.1007/ s43465-020-00135-1. 
5. Gruskay JA, Dvorzhinskiy A, Konnaris MA, LeBrun DG, Ghahramani GC, Premkumar A, et al. Universal Testing for COVID-19 in Essential Orthopaedic Surgery Reveals a High Percentage of Asymptomatic Infections. J Bone Joint Surg Am. 2020 Jun 8 (published online ahead of print). DOI:10.2106/JBJS.20.01053

6. Meng Y, Leng K, Shan L, Guo M, Zhou J, Tian Q, et al. A clinical pathway for pre-operative screening of COVID-19 and its influence on clinical outcome in patients with traumatic fractures. Int Orthop. 2020 Aug;44(8): 1549-55. DOI: 10.1007/s00264-020-04645-3.

7. Ambrosio L, Vadalà G, Russo F, Papalia R, Denaro V. The role of the orthopaedic surgeon in the COVID-19 era: cautions and perspectives. J Exp Orthop. 2020 May;7(1):35. DOI: 10.1186/s40634-020-00255-5

8. Nuñez JH, Sallent A, Lakhani K, Guerra-Farfan E, Vidal N, Ekhtiari S, et al. Impact of the COVID-19 Pandemic on an Emergency Traumatology Service: Experience at a Tertiary Trauma Centre in Spain. Injury. 2020 Jul;51(7): 1414-8. DOI: 10.1016/j.injury.2020.05.016

9. Wong JSH, Cheung KMC. Impact of COVID-19 on Orthopaedic and Trauma Service: An Epidemiological Study. J Bone Joint Surg Am. 2020 Jul;102(14):1-9. DOI:10.2106/JBJS.20.00775

10. Benazzo F, Rossi SMP, Maniscalco P, Moretti B, Vaienti E, Ruggieri P, et al. The orthopaedic and traumatology scenario during Covid-19 outbreak in Italy: chronicles of a silent war. Int Orthop. 2020 Aug;44(8):1453-9. DOI: $10.1007 / \mathrm{s} 00264-020-04637-3$

11. Lal H, Sharma DK, Patralekh MK, Jain VK, Maini L. Out Patient Department practices in orthopaedics amidst COVID-19: The evolving model. J Clin Orthop Trauma. 2020;11(4):700-12. DOI: 10.1016/j.jcot.2020.05.009

12. Farrell S, Schaeffer EK, Mulpuri K. Recommendations for the Care of Pediatric Orthopaedic Patients During the COVID-19 Pandemic. J Am Acad Orthop Surg. 2020 Jun;28(11):477-86. DOI: 10.5435/JAAOS-D-20-00391

13. Hamal PK, Dangal G, Gyanwali P, Jha AK. Let Us Fight Together against COVID-19 Pandemic. Journal of Nepal Health Research Council. 2020;18(46):I-II. DOI: 10.33314/jnhrc.v18i1.2628

14. Jain A, Jain P, Aggarwal S. SARS-CoV-2 Impact on Elective Orthopaedic Surgery: Implications for Post-Pandemic Recovery. J Bone Joint Surg Am. 2020 Jul;102(13):e68. DOI: 10.2106/JBJS.20.00602

15. Baghdadi S, Nabian MH, Baghdadi T. Bone in the Time of Corona: Suggestions for Managing Paediatric Orthopaedics Conditions in a Resource-limited Environment during the COVID-19 Pandemic. Arch Bone Jt Surg. 2020 Apr;8(1):231-4. DOI: 10.22038/ABJS.2020.47715.2340.

16. Park C, Sugand K, Nathwani D, Bhattacharya R, Sarraf KM. Impact of the COVID-19 pandemic on orthopedic trauma workload in a London level 1 trauma center: the "golden month": The COVID Emergency Related Trauma and orthopaedics (COVERT) Collaborative. Acta Orthopaedica. 2020;91:1-6. DOI: $10.1080 / 17453674.2020 .1783621$

17. Abdelnasser MK, Morsy M, Osman AE, AbdelKawi AF, Ibrahim MF, Eisa A, et al. COVID-19. An update for orthopedic surgeons. SICOT-J. 2020;6:24. DOI: 10.1051/sicotj/2020022

18. Neradi D, Hooda A, Shetty A, Kumar D, Salaria AK, Goni V. Management of Orthopaedic Patients During COVID-19 Pandemic in India: A Guide. Indian J Orthop. 2020;54(3):402-7. DOI: 10.1007/s43465-020-00122-6

19. Pradhan NMS, Acharya BM, Devkota P, Gyawali B, Bhatta TR, Pokhrel PM, et al. Orthopaedic services during COVID-19 lockdown at Patan Hospital, Nepal. JPAHS. 2020 Apr;7(1):19-24. DOI: 10.3126/jpahs.v7i1.28858

20. Tamburrelli FC, Meluzio MC, Perna A, Santagada DA, Genitiempo M, Zirio G, et al. Spinal surgery in COVID-19 pandemic era: One trauma hub center experience in central-southern Italy. Journal of Orthopaedics. 2020 Nov; 22:291-3. DOI: $10.1016 /$ j.jor.2020.06.014

21. Massey PA, McClary K, Zhang AS, Savoie FH, Barton RS. Orthopaedic Surgical Selection and Inpatient Paradigms During the Coronavirus (COVID-19) Pandemic. J Am Acad Orthop Surg. 2020 Jun 1;28(11):436-50. DOI: 10.5435/JAAOS-D-20-00360

22. Sarac NJ, Sarac BA, Schoenbrunner AR, Janis JE, Harrison RK, Phieffer LS, et al. A Review of State Guidelines for Elective Orthopaedic Procedures During the COVID-19 Outbreak. J Bone Joint Surg Am. 2020 Jun;102(11):942-5. DOI: 10.2106/JBJS.20.00510 PMID: 32282419 